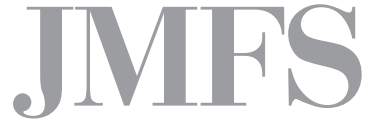

Journal of Management and Financial Sciences
Volume XII

Issue 36 (March 2019)

pp. $73-83$

Warsaw School of Economics

Collegium of Management and Finance

Michał Suchanek

Faculty of Economics

University of Gdansk

\title{
Relations between transport choices and active behaviour
}

\begin{abstract}
Unhealthy lifestyle choices and passive behaviour are a significant problem for many developed countries. They lead to a decrease in public health in the form of diseases related to contemporary civilization, such as: cardiovascular diseases, type II diabetes and obesity. This increases the costs generated in the healthcare system. The share of costs resulting from combating these diseases increases every year.

The choice of a transport mode used when commuting is often perceived as one of the factors leading to more proactive behaviour and thus decreasing the externalities not only connected directly with transport such as pollution, noise, congestion and accidents, but also those connected with public health.

The paper shows the results of a study performed in Poland, which was meant to identify and measure the relations between the transport choices and other proactive choices of commuters. A logistic regression model was estimated to identify the occurrence and intensity of these relations.

The goal of the article is, therefore, to assess whether the choice of a transport mode used when commuting is connected with other types of proactive behaviour of citizens. In particular, the author wishes to determine if people choosing a car as their mode of transport tend to be generally less active than people choosing public transport or those who commute actively.
\end{abstract}

Keywords: transport choices, public health, transport behaviour

JEL Classification Codes: C35, D12, R41 


\section{Introduction}

Public health is one of the main factors of sustainable development of economies and societies. Transport is often perceived as one of the factors determining sustainability. This is due to the fact that the choice of the mode of transport results in the generation of various externalities, such as external costs of pollution, noise or accidents. However, it is worth noticing that transport is also connected with the externalities connected with public health. The very choice of a transport mode has an effect on an individual's state of health. It determines both the physical and the mental health condition of a person [Suchanek, 2018].

It is widely accepted that public health is determined by the physical environment, social environment, lifestyle and health behaviour, medical care and genetics [McGovern et al., 2014]. The relations between the physical environment and social environment and transport have been widely researched [among others: Lucas et al., 2001; Wilkinson et al., 2003; Giles-Corti, Donovan, 2002]. It is thus worth assessing whether the lifestyle and pro-health behaviour also determines the transport choices of commuters. Even though the current society is often described as a society in motion and a society which is very proactive [Lash, Urry, 2003], the modal decisions of commuters often prove otherwise because in most European countries, a personal car is still the transport mode of choice when it comes to commuting [Sierpiński, 2013]. This creates a plausible contradiction when analysed together with the rising levels of physical activity [Althoff et al., 2017]. This is certainly a problem worth researching.

The goal of the article is, therefore, to assess whether the choice of a transport mode used when commuting is connected with other types of proactive behaviour of citizens. In particular, the author wishes to determine if people choosing a car as their mode of transport tend to be generally less active than people choosing public transport or commute actively.

\section{Proactive behaviour as a potential determinant of the transport mode choice}

The fact that societies, especially in the developed countries, tend to show a low level of physical activity is an increasingly important problem [Ding et al., 2016]. Lower levels of physical activity generally result in a decline in public health, especially if the activity level is extremely low [Sallis et al., 2016]. This is why one of the overall tendencies, especially visible in the European Union policy framework, is to promote proactive behaviour, among others, through the choice of more active transport modes. The general assumption seems to be that the promotion of a healthy, active lifestyle should result in more sustainable transport behaviour, such as commuting with public transport or in an active way. However, it is not clear whether a more active lifestyle results in a more active transport behaviour. The studies' results seem to be inconclusive [Shaw et al., 2017]. 
In fact, the level of active behaviour, measured either as a form of self-perception or in an objective manner is rarely pinpointed as one of the determinants of the mode of transport choice. The choice of a mode of transport is a choice which is the consequence of the transport need, either an obligatory or facultative one and is, therefore, dependent on a plethora of factors [Wyszomirski, 2008]. The reasons for the choice of a particular transport mode are the consequence of the attributes of the transport means [Hebel, 2013]. Price, travel time and the overall quality are often said to be the main deciding factors, but the precise list of factors and their weight is different when it comes to individual transport, public transport and active commuting. When it comes to travelling by car, the main deciding factors are: convenience, short travel time, a lack of convenient public transport connections. For the public transport factors such as good public transport offer, lower costs and congestion are usually taken into account [Kłos-Adamkiewicz, 2017]. Other studies point out that the reasons behind the transport choice are far less rational and depend on psychological determinants including the psychological profile of a commuter in regard to the: needs for autonomy, needs for personal space and sense of identity [Wyszomirska-Góra, 2013]. Nevertheless, choosing public transport rarely seems to be the result of a generally proactive nature of a commuter.

\section{Material and methods}

The collected data consists of 243 observations collected from the residents of the Tricity Metropolitan Area in Northern Poland using the CAWI method. The collected data was used to create 26 variables, with scales varying from nominal to ratio. Three synthetic variables were created: Body Mass Index (BMI), Non-Specific Psychological Distress (NSPD), Main Commute Mode. The BMI variable was created by dividing the weight measured in kilograms by squared height measured in meters. The NSPD variable was created by summing up the six variables, which constituted the self-assessment of the mental health using Kessler's Non-Specific Psychological Distress Scale. They were as follows [Kessler et al., 2002]:

- how often do you feel sad?

- how often do you feel nervous?

- how often do you feel restless?

- how often do you feel hopeless?

- how often do you feel everything is an effort?

- how often do you feel worthless?

After the construction of the synthetic variable, an internal consistency and accuracy analysis was performed (Table 1).

The consistency analysis showed an overall value of the Alpha-Cronbach parameter equal to 0.87 , which together with the analysis of the values in the table leads to an assumption that the variable was properly constructed. 
Table 1. Consistency analysis for the NSPD variable

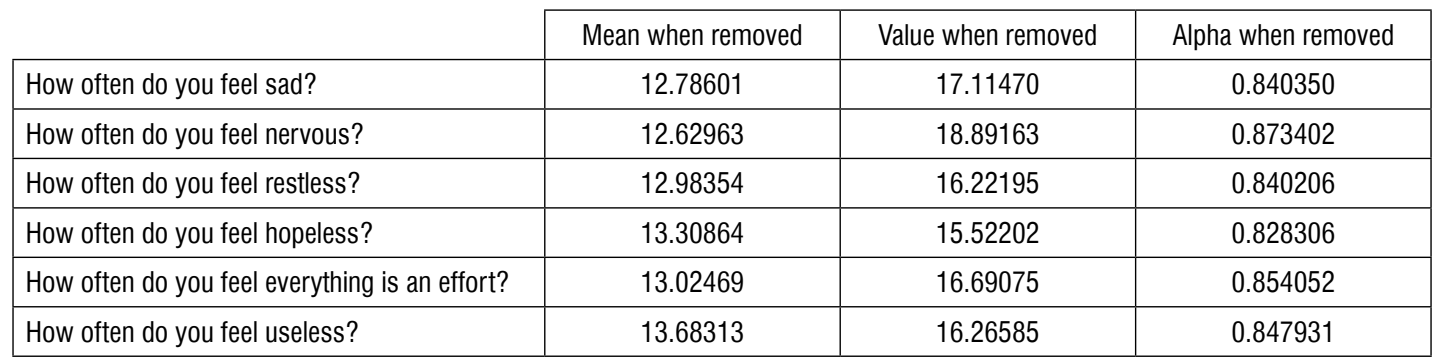

Source: own study.

The last synthetic variable was the Main Commute Mode, which was constructed based on the respondents' answers to the question on what basis was their main transport mode chosen when commuting. They could declare that they used: a car, tram, bus, trolley, railway transport, bike or that they travelled on foot. Their answers were aggregated to three categories of the variable: car, public transport, active commute.

The relations between the main commute mode and all the nominal variables analysed are shown in Table 2.

Table 2. Contingency table - nominal variables and main commute mode

\begin{tabular}{|c|c|c|c|}
\hline & $\begin{array}{c}\text { Main Commute Mode } \\
\text { - Car }\end{array}$ & $\begin{array}{l}\text { Main Commute Mode } \\
\text { - Public Transport }\end{array}$ & $\begin{array}{l}\text { Main Commute Mode } \\
\text { - Active Commute }\end{array}$ \\
\hline \multicolumn{4}{|c|}{ How often do you consume alcohol? } \\
\hline A few times a week & 5 & 13 & 6 \\
\hline A few times a month & 21 & 80 & 18 \\
\hline Once a month & 10 & 27 & 7 \\
\hline Less than once a month & 3 & 27 & 9 \\
\hline Not at all & 5 & 11 & 1 \\
\hline \multicolumn{4}{|c|}{ Do you smoke? } \\
\hline Yes & 8 & 16 & 6 \\
\hline Rarely & 8 & 30 & 7 \\
\hline No & 28 & 112 & 28 \\
\hline \multicolumn{4}{|c|}{ How often do you do any sport? } \\
\hline A few times a week & 16 & 41 & 15 \\
\hline A few times a month & 17 & 69 & 13 \\
\hline Once a month & 5 & 11 & 6 \\
\hline Less than once a month & 5 & 20 & 3 \\
\hline Not at all & 1 & 17 & 4 \\
\hline \multicolumn{4}{|c|}{ Do you eat healthy? } \\
\hline Not & 1 & 4 & 2 \\
\hline Rather not & 5 & 19 & 3 \\
\hline Moderately & 11 & 32 & 10 \\
\hline
\end{tabular}




\begin{tabular}{|c|c|c|c|}
\hline & $\begin{array}{l}\text { Main Commute Mode } \\
\text { - Car }\end{array}$ & $\begin{array}{l}\text { Main Commute Mode } \\
\text { - Public Transport }\end{array}$ & $\begin{array}{l}\text { Main Commute Mode } \\
\text { - Active Commute }\end{array}$ \\
\hline Rather yes & 24 & 89 & 22 \\
\hline Yes & 3 & 14 & 4 \\
\hline \multicolumn{4}{|c|}{ Are you active? } \\
\hline Not & 2 & 7 & 1 \\
\hline Rather not & 4 & 32 & 7 \\
\hline Moderately & 2 & 32 & 8 \\
\hline Rather yes & 27 & 70 & 19 \\
\hline Yes & 9 & 17 & 6 \\
\hline \multicolumn{4}{|c|}{ Area of residence } \\
\hline Rural & 3 & 20 & 6 \\
\hline Urban less than $10 \mathrm{k}$ & 0 & 4 & 2 \\
\hline Urban 10-50k & 4 & 18 & 8 \\
\hline Urban 50-100k & 3 & 15 & 2 \\
\hline Urban above 100k & 34 & 101 & 23 \\
\hline \multicolumn{4}{|c|}{ Marital status } \\
\hline Single & 16 & 55 & 26 \\
\hline Informal relationship & 24 & 97 & 15 \\
\hline Married & 4 & 6 & 0 \\
\hline \multicolumn{4}{|c|}{ Diabetes type II } \\
\hline Yes & 1 & 3 & 0 \\
\hline No & 43 & 155 & 41 \\
\hline \multicolumn{4}{|l|}{ Hypertension } \\
\hline Yes & 1 & 3 & 2 \\
\hline No & 43 & 155 & 39 \\
\hline
\end{tabular}

Source: own study.

The variables which were taken into account were supposed to represent a wide variety of pro-active behaviour, as well as the physical and mental condition of a commuter [Tajalli, Hajbabaie, 2017, pp. 4-5).

Based on the collected data, three logistic regression models were generated. Their objective was to show which factors affect the choice of the transport mode when commuting. The logistic regression models all included the Main Commute Mode as the dependent variable and the outcomes were modelled in pairs: car/public transport, car/active commute and public transport/active commute.

\section{Results}

The first logistic regression model shows how the choice between the car and public transport is affected by various factors (Table 3 ). 
Table 3. Logistic regression - commute mode - pair car/public transport

\begin{tabular}{|c|c|c|c|}
\hline Effect & Level & Value & $p$ \\
\hline \multicolumn{2}{|c|}{ Const. } & -3.0001 & 0.184388 \\
\hline \multicolumn{2}{|c|}{ How many sodas do you drink weekly? } & 0.0788 & 0.390823 \\
\hline \multicolumn{2}{|c|}{ Disposable income } & 0.0008 & 0.015644 \\
\hline \multicolumn{2}{|c|}{ No. of people in the household } & 0.2965 & 0.129012 \\
\hline \multicolumn{2}{|c|}{ How many fruit/vegetable portions a day do you eat? } & -0.3020 & 0.253691 \\
\hline \multicolumn{2}{|c|}{ Commute time (minutes) } & -0.0911 & 0.000092 \\
\hline NSPD & & -0.0272 & 0.655285 \\
\hline BMI & & 0.0007 & 0.975289 \\
\hline Diabetes type II & Yes & -0.0160 & 0.983820 \\
\hline Gender & 1 & -0.2645 & 0.346257 \\
\hline Marital Status & Single & -0.2758 & 0.562934 \\
\hline Marital Status & Informal relationship & -0.7235 & 0.104105 \\
\hline Residence & Rural & 3.1549 & 0.022714 \\
\hline Residence & Urban less than $10 \mathrm{k}$ & -14.7623 & 0.000000 \\
\hline Residence & Urban 10-50k & 3.6263 & 0.002653 \\
\hline Residence & Urban 50-100k & 3.7665 & \\
\hline Are you active? & No & -0.3364 & 0.720713 \\
\hline Are you active? & Rather not & -0.3936 & 0.564181 \\
\hline Are you active? & Moderately & -1.9773 & 0.020592 \\
\hline Are you active? & Rather yes & 0.9558 & 0.049983 \\
\hline Do you eat healthy? & No & 2.3968 & 0.069908 \\
\hline Do you eat healthy? & Rather not & -0.7457 & 0.308323 \\
\hline Do you eat healthy? & Moderately & 0.6843 & 0.248104 \\
\hline Do you eat healthy? & Rather yes & -0.2563 & 0.615995 \\
\hline How often do you do any sport? & A few times a week & 0.1067 & 0.854167 \\
\hline How often do you do any sport? & A few times a month & -0.4621 & 0.369489 \\
\hline How often do you do any sport? & Once a month & 1.5739 & 0.060995 \\
\hline How often do you do any sport? & Less than once a month & 0.5736 & 0.404382 \\
\hline Do you smoke? & Yes & 0.8230 & 0.118411 \\
\hline Do you smoke? & Rarely & -0.3964 & 0.439106 \\
\hline How often do you consume alcohol? & A few times a week & -0.2610 & 0.716053 \\
\hline How often do you consume alcohol? & A few times a month & -0.0133 & 0.976945 \\
\hline How often do you consume alcohol? & Once a month & 0.9948 & 0.085106 \\
\hline How often do you consume alcohol? & Less than once a month & -1.4537 & 0.114393 \\
\hline Hypertension & Yes & 0.0066 & 0.993331 \\
\hline Scale & & 1.0000 & \\
\hline
\end{tabular}

Source: own study.

The only variables which are the statistically significant predictors in this model are: disposable income, commute time, residence and the self-perception of being active. The 
three first factors are objective and they have nothing to do with the pro-active behaviour of a commuter. What is interesting is that the choice is also affected by whether the commuter perceives himself or herself as being active, whereas it is not affected by any other pro-health behaviour indicators such as healthy eating, smoking, consuming alcohol or engaging in sporting activities. This might suggest that in this case the choice is not related to the pro-active behaviour itself but in fact to the sense of identity of the commuter who defines his or her pro-active behaviour through his/her transport choice.

The second logistic regression model shows how the choice between a car and active commute is affected by various factors (Table 4)

Table 4. Logistic regression - commute mode - pair car/active commute

\begin{tabular}{|c|c|c|c|}
\hline Effect & Level & Value & $p$-value \\
\hline Const. & & -51.2299 & 0.012603 \\
\hline \multicolumn{2}{|c|}{ Disposable income } & 0.0018 & 0.181053 \\
\hline \multicolumn{2}{|c|}{ No. of people in the household } & 1.4185 & 0.145279 \\
\hline \multicolumn{2}{|c|}{ How many sodas do you drink weekly? } & 1.8994 & 0.013521 \\
\hline \multicolumn{2}{|c|}{ How many fruit/vegetable portions a day do you eat? } & -0.0282 & 0.973505 \\
\hline \multicolumn{2}{|c|}{ Commute time (minutes) } & 0.1687 & 0.111502 \\
\hline NSPD & & 0.3778 & 0.061304 \\
\hline BMI & & 1.1315 & 0.021278 \\
\hline Gender & 1 & 1.5665 & 0.171091 \\
\hline Marital Status & Single & -6.2423 & 0.003230 \\
\hline Marital Status & Informal relationship & -3.5823 & \\
\hline Residence & Rural & 0.5528 & 0.961460 \\
\hline Residence & Urban less than $10 \mathrm{k}$ & -14.1006 & 0.667755 \\
\hline Residence & Urban 10-50k & -1.5937 & 0.891783 \\
\hline Residence & Urban 50-100k & 7.9646 & \\
\hline Are you active? & No & 9.7872 & 0.079213 \\
\hline Are you active? & Rather not & -3.1813 & 0.104439 \\
\hline Are you active? & Moderately & -10.1339 & 0.016204 \\
\hline Are you active? & Rather yes & -0.4728 & 0.706968 \\
\hline Do you eat healthy? & No & -5.4815 & 0.177575 \\
\hline Do you eat healthy? & Rather not & 19.3169 & 0.023980 \\
\hline Do you eat healthy? & Moderately & -4.9116 & 0.107413 \\
\hline Do you eat healthy? & Rather yes & -2.9387 & 0.236735 \\
\hline How often do you do any sport? & A few times a week & 1.0743 & 0.550345 \\
\hline How often do you do any sport? & A few times a month & 1.1644 & 0.539695 \\
\hline How often do you do any sport? & Once a month & -0.2005 & 0.943574 \\
\hline How often do you do any sport? & Less than once a month & 12.6606 & 0.018931 \\
\hline Do you smoke? & Yes & 6.4590 & 0.024659 \\
\hline Do you smoke? & Rarely & -4.4988 & 0.039612 \\
\hline
\end{tabular}




\begin{tabular}{|l|l|r|c|}
\hline \multicolumn{1}{|c|}{ Effect } & \multicolumn{1}{c|}{ Level } & \multicolumn{1}{c|}{ Value } & p-value \\
\hline How often do you consume alcohol? & A few times a week & -6.7477 & 0.025302 \\
\hline How often do you consume alcohol? & A few times a month & 2.7773 & 0.080869 \\
\hline How often do you consume alcohol? & Once a month & -1.7282 & 0.334512 \\
\hline How often do you consume alcohol? & Less than once a month & -15.9713 & 0.025982 \\
\hline Hypertension & Yes & -14.7368 & 0.021873 \\
\hline Diabetes type II & Yes & 2.3457 & \\
\hline Scale & & 1.0000 & \\
\hline
\end{tabular}

Source: own study.

In this case, the variables which proved to be statistically significant are: the number of fizzy drinks consumed per week (the car users on general drink more soda), BMI (an increase in BMI by one point increases the chance of using a car as the mode of transport by $1.13 \%$ ), marital status, healthy diet (people who keep a healthy diet are less likely to choose a car as their mode of transport), being active (people perceiving themselves as being active are less likely to choose a car as their mode of transport), doing sport (people who engage in sporting activities less than once a month are $12 \%$ more likely to commute by car), smoking, consumption of alcohol (both the smokers and the drinkers are more likely to commute by car) and hypertension. This is a radically different set of significant variables than in the case of the first model. Whereas in the choice between a car and public transport objective factors played the key role, here it is in fact the proactive behaviour which matters. The choice between the active commute by bike or on foot and the commute by car is affected by the overall prohealth behaviour of a given commuter. What is worth noticing is that neither the commute time nor the disposable income are important factors when choosing between a car and the active commute.

The third logistic regression model shows how the choice between public transport and active commute is affected by various factors (Table 5).

Table 5. Logistic regression - commute mode - pair public transport/active commute

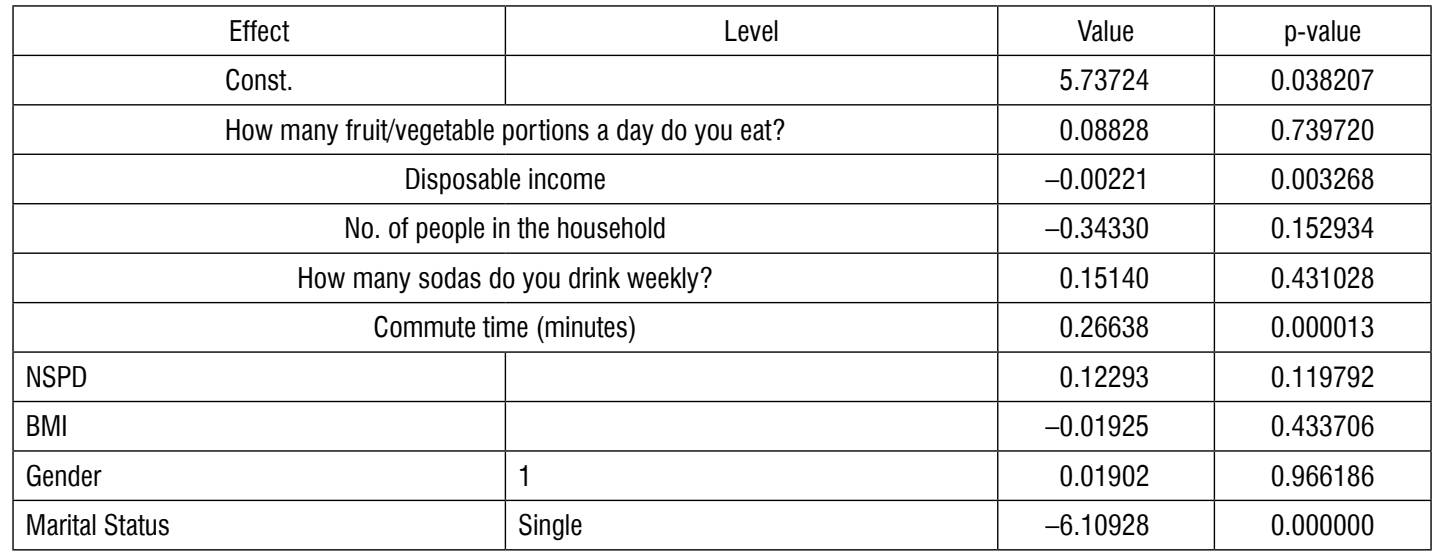




\begin{tabular}{|c|c|c|c|}
\hline Effect & Level & Value & $p$-value \\
\hline Marital Status & Informal relationship & -4.92535 & \\
\hline Residence & Rural & -1.54654 & 0.113054 \\
\hline Residence & Urban less than $10 \mathrm{k}$ & 2.25253 & 0.127004 \\
\hline Residence & Urban 10-50k & 0.30030 & 0.738752 \\
\hline Residence & Urban $50-100 \mathrm{k}$ & -0.53593 & 0.658753 \\
\hline Are you active? & No & -0.13718 & 0.919575 \\
\hline Are you active? & Rather not & 1.32934 & 0.183898 \\
\hline Are you active? & Moderately & 0.73294 & 0.367134 \\
\hline Are you active? & Rather yes & -1.01484 & 0.141617 \\
\hline Do you eat healthy? & No & -6.27227 & 0.002956 \\
\hline Do you eat healthy? & Rather not & 2.13650 & 0.115396 \\
\hline Do you eat healthy? & Moderately & 1.73839 & 0.046286 \\
\hline Do you eat healthy? & Rather yes & 1.08280 & 0.164165 \\
\hline How often do you do any sport? & A few times a week & 0.32198 & 0.684323 \\
\hline How often do you do any sport? & A few times a month & 1.53336 & 0.029350 \\
\hline How often do you do any sport? & Once a month & -2.64127 & 0.020530 \\
\hline How often do you do any sport? & Less than once a month & -0.38368 & 0.723509 \\
\hline Do you smoke? & Yes & 0.33772 & 0.647800 \\
\hline Do you smoke? & Rarely & -0.75394 & 0.342910 \\
\hline How often do you consume alcohol? & A few times a week & -0.81015 & 0.482787 \\
\hline How often do you consume alcohol? & A few times a month & 0.26679 & 0.740455 \\
\hline How often do you consume alcohol? & Once a month & -0.06877 & 0.944565 \\
\hline How often do you consume alcohol? & Less than once a month & -1.40380 & 0.175828 \\
\hline Hypertension & Yes & -2.74876 & 0.094445 \\
\hline Diabetes type II & Yes & 7.02157 & \\
\hline Scale & & 1.00000 & \\
\hline
\end{tabular}

Source: own study.

In this case, the significant variables are: disposable income, commute time, marital status, healthy behaviour and engagement in sports activities. The results show that the choice of public transport is heavily affected by the objective variables, as was the case with the choice between a car and public transport. Still, some pro-health behaviour factors affect the choice. People who maintain a healthy diet and engage in sports activities are generally more prone to choose an active way of commuting. This is, however, outweighed by the significance of the commute time. The longer the commute time, the more likely commuters are to choose public transport over a bike or a commute on foot. 


\section{Summary}

The results show that the factors which affect the transport choice of a commuter are heavily dependent on the choice which he/she makes. If the commuter chooses between a car and public transport or the active commute and public transport, his or her choice is bound to be heavily dependent on objective factors such as disposable income, residence area and, above others, the commute time. If, however, the choice is between a car and the active commute by bike or on foot, the commuter's choice is far more likely to be affected by his or her general proactive and pro-health behaviour. This is not a conclusion which is in line with promoting the public transport commute as a way of improving the physical activity of the population. In fact, public transport seems to be the mode of transport which is chosen by people due to objective factors and not as a lifestyle choice. If the members of the population who are objectively proactive can commute in an active way, they are likely to do so. If, however, this is out of the question due to an objective factor like the commute time, their choice between commuting by car and by public transport is likely to be determined by other objective factors, such as disposable income and not by their general proactive behaviour. This shows that despite the efforts, public transport is still not perceived as a proactive mode of commuting.

Therefore, if the goal of policymakers is to promote more proactive behaviour with the thought of increasing the level of public health in mind, they are more likely to succeed by promoting active commuting than public transport. Solutions such as bike-sharing systems seem to fit in that trend. One thing worth noting is that, even though the choice of public transport is not determined by objective proactive behaviour, it is in fact determined by the perception of being active. This suggests that a more intensive promotion of public transport as a proactive way of commuting might result in a different image of that mode of transport and in turn in a modal switch in that direction. However, it also shows that further study is necessary regarding the effect which psychological factors, including the personality profile, have on the transport behaviour of the population.

\section{References}

1. Althoff, T., Hicks, J.L., King, A.C., Delp, S.L., \& Leskovec, J. (2017). Large-scale physical activity data reveal worldwide activity inequality. Nature, 547(7663), pp. 336.

2. Ding, D., Lawson, K.D., Kolbe-Alexander, T.L., Finkelstein, E.A., Katzmarzyk, P.T., Van Mechelen, W. \& Lancet Physical Activity Series 2 Executive Committee (2016). The economic burden of physical inactivity: a global analysis of major non-communicable diseases. The Lancet, 388(10051), pp. 1311-1324.

3. Giles-Corti, B., \&Donovan, R.J. (2002). The relative influence of individual, social and physical environment determinants of physical activity. Social science \& medicine, 54(12), pp. 1793-1812. 
4. Hebel, K. (2013). Zachowania transportowe mieszkańców w kształtowaniu transport miejskiego. Gdańsk: Wydawnictwo Uniwersytetu Gdańskiego, pp. 13-24.

5. Kessler, R.C., Andrews, G., Colpe, L.J., Hiripi, E., Mroczek, D.K., Normand, S.L.T., Walters, E.E., Zaslavsky, A.M. (2002). Short screening scales to monitor population prevalences and trends in non-specific psychological distress. Psychological Medicine 32, pp. 959-976.

6. Kłos-Adamkiewicz, Z. (2017). Hierarchizacja czynników mających wpływ na wybór środka transportu do codziennych podróży na przykładzie Szczecina. Zeszyty Naukowe Uniwersytetu Gdańskiego. Ekonomika Transportu i Logistyka, (62 Wyzwania rozwoju transportu. Ujęcie gałęziowe), pp. 9-20.

7. Lash, S., \& Urry, J. (1993). Economies of signs and space (Vol. 26). Tjousand Oaks, California, USA: Sage.

8. Lucas, K., Grosvenor, T., \& Simpson, R. (2001). Transport, the environment and social exclusion. York: York Publishing Series.

9. McGovern, L., Miller, G., Hughes-Cromwick, P. (2014). The Relative Contribution of Multiple Determinants to Health Outcomes. Project HOPE.

10. Sallis, J.F., Bull, F., Guthold, R., Heath, G.W., Inoue, S., Kelly, P. \& Lancet Physical Activity Series 2 Executive Committee (2016). Progress in physical activity over the Olympic quadrennium. The Lancet, 388(10051), pp. 1325-1336.

11. Shaw, C., Keall, M., \& Guiney, H. (2017). What modes of transport are associated with higher levels of physical activity? Cross-sectional study of New Zealand adults. Journal of Transport \& Health, Vol. 7, pp. 125-133.

12. Sierpiński, G. (2013). Changes of the modal split of traffic in Europe. Archives of Transport System Telematics, Vol. 6, pp. 44-47.

13. Suchanek, M. (2018). New Research Trends in Transport Sustainability and Innovation: Transopot 2017 Conference. Springer.

14. Wilkinson, R.G. \& Marmot, M. (Eds.). (2003). Social determinants of health: the solid facts. World Health Organization.

15. Wyszomirska-Góra, M. (2013). Psychologiczne determinanty wyboru środka transportu w codziennych podróżach miejskich. Transport Miejski i Regionalny, Vol. 1, pp. 4-9.

16. Wyszomirski, O. (2008). Transport miejski. Ekonomika i organizacja. Gdańsk: Wydawnictwo Uniwersytetu Gdańskiego. 